\title{
Plasma Transferrin Concentration as a Nutritional Marker in Malnourished Dogs with Nutritional Treatment
}

\author{
Mayumi NAKAJIMA ${ }^{1)}$, Koichi OHNO ${ }^{1) *}$, Yuko GOTO-KOSHINO ${ }^{1)}$, Yasuhito FUJINO ${ }^{1)}$ and Hajime TSUJIMOTO ${ }^{1)}$ \\ ${ }^{1)}$ Department of Veterinary Internal Medicine, Graduate School of Agricultural and Life Sciences, The University of Tokyo, 1-1-1 Yayoi, \\ Bunkyo-ku, Tokyo 113-8657, Japan
}

(Received 20 November 2013/Accepted 9 December 2013/Published online in J-STAGE 20 December 2013)

ABSTRACT. Rapid turnover proteins, such as transferrin (Tf), are used as dynamic nutritional assessment proteins in human medicine. However, nutritional status in veterinary medicine is mostly assessed on the basis of classical static factors, such as body weight, body condition score and plasma albumin level. This study evaluated the clinical usefulness of Tf as a nutritional assessment marker by measuring plasma Tf concentrations in malnourished dogs before and after nutritional treatment. Posttreatment plasma Tf concentrations were significantly higher than the pretreatment concentrations, although the albumin concentration did not change significantly. The numbers of dogs that exhibited increases in plasma Tf concentrations were significantly related to weight gain. Furthermore, the survival rates at day 60 after treatment initiation were significantly higher in dogs with plasma Tf concentrations above the reference value $(180 \mathrm{mg} / \mathrm{d} l)$ after the nutritional treatment than in those with a plasma Tf concentration $<180 \mathrm{mg} / \mathrm{d} l$. In conclusion, the plasma Tf concentration is related to nutritional condition and would be a candidate for a novel nutritional assessment marker in dogs.

KEY WORDS: nutritional assessment, rapid turnover protein, transferrin.

doi: 10.1292/jvms.13-0583; J. Vet. Med. Sci. 76(4): 539-543, 2014

Malnutrition negatively affects the recovery process in various diseases. Compromised immune function and delayed wound healing are reported in humans with malnutrition $[3,9,26,27,30,32,35]$. Effective nutritional therapy improves mortality in malnourished surgical patients or seriously ill patients [11, 16, 19, 29]. Nutritional assessment should be the first step to provide appropriate nutritional treatment [22].

In dogs, malnutrition during hospitalization is reported to impair clinical signs and prognosis $[4,25]$. The nutritional status of diseased dogs is currently estimated on the basis of body weight $[2,17,18]$, body condition score (BCS) $[17,18]$ and several serum biochemical values [17]. Body weight change is the most reliable factor for assessing nutritional status. However, it is a static factor and does not reflect short-term changes. In addition, fluid accumulation in the third space directly affects body weight, making assessment difficult. Although BCS is a convenient and noninvasive method for estimating the nutritional status of dogs, it is a subjective marker and is influenced by body size and shape among different breeds. The plasma albumin concentration is a biochemical parameter commonly used to assess nutritional status in dogs [17]. As the half-life of albumin is 20 days in humans [33] and 8.2 days in dogs [6], it is expected to be a short- to medium-term nutritional assessment marker.

CORRESPONDENCE TO: OHNo, K., Department of Veterinary Internal Medicine, Graduate School of Agricultural and Life Sciences, The University of Tokyo, 1-1-1 Yayoi, Bunkyo-ku, Tokyo 113-8657, Japan. e-mail: aohno@mail.ecc.u-tokyo.ac.jp

(C)2014 The Japanese Society of Veterinary Science

This is an open-access article distributed under the terms of the Creative Commons Attribution Non-Commercial No Derivatives (by-nc-nd) License $<$ http://creativecommons.org/licenses/by-nc-nd/3.0/>.
However, the plasma albumin concentration is readily influenced by fluid accumulation, hepatic function and protein loss from the gut and kidneys. In addition, it rarely decreases unless malnutrition is in the advanced stage, possibly in part because of the large capacity of the liver to synthesize albumin [28].

Tf is mainly synthesized in the liver and plays an important role in iron transport [14]. Decreased intestinal protein uptake promptly reduces Tf production, which directly depletes the plasma $\mathrm{Tf}$ concentration $[5,10]$. We previously reported that plasma $\mathrm{Tf}$ concentrations are decreased in experimentally induced undernourished dogs, suggesting that Tf may be a dynamic nutritional marker in dogs [21]. Therefore, this study evaluated the relationships between plasma $\mathrm{Tf}$ concentration and the nutritional condition and prognosis in diseased dogs receiving nutritional treatment.

\section{MATERIALS AND METHODS}

Dogs and nutritional treatment: Thirty-three dogs referred to the Veterinary Medical Center of the University of Tokyo with clinical signs of anorexia (i.e., taking $<50 \%$ of the resting energy requirement [RER] per day over 3 days) were included in this study. Caloric intake was estimated on the basis of interviews with the dogs' owners before nutritional treatment. RER was calculated by the following formula: $\mathrm{RER}=70 \times(\text { body weight in } \mathrm{kg})^{0.75}$ [4]. All dogs received nutritional treatments that met their respective RER through oral-assisted feeding (OF), enteral-assisted feeding (EF) including esophagostomy, gastrostomy or jejunostomy tube feeding, or parenteral-assisted feeding (PF). The OF and EF dogs, except for jejunostomy tube feeding, were fed mainly semi-digestion liquid diet (CliniCare, Abbott Laboratories, Abbott Park, IL, U.S.A.) or high density diet (a/d, Hill's 
Pet Nutrition, Topeka, KS, U.S.A.). For jejunostomy tube feeding, a highly digested nutrition agent (Convalescence Support, Royal Canin, Aimargues, France) was used. The $\mathrm{PF}$ dogs received continuous intravenous fluids prepared by mixing dextrose, lipid and amino acid products to meet the RER for each patient. Body weight, BCS and plasma Tf and albumin concentrations were monitored in all dogs before and after the nutritional treatment. Dogs with incomplete medical records or liver failure were excluded from this study.

Subject characteristics: For the purpose of evaluating the relationships between the plasma Tf concentration and the effect of nutritional treatment, dogs with pleural effusion and ascites were excluded in order to accurately measure body weight changes. Twenty-one of the 33 anorexic dogs were included for this purpose; 9 were female ( 3 intact), and 12 were male (6 intact). The median age was 113 months (range: 7-173 months), and the median BCS was 2/5 (range: 1-3). The primary disease causing malnutrition was chronic inflammatory gastrointestinal disease in 6 dogs; pancreatitis in 3 dogs; pyloric stenosis in 2 dogs; and lymphangiosarcoma, gastric adenocarcinoma, gastric delayed emptying, oral melanoma, holoprosencephaly, gastrointestinal lymphoma, esophageal diverticulum, megaesophagus, myelodysplastic syndrome and encephalomyelitis in 1 dog each, respectively. The nutritional treatments performed included OF only $(n=11), E F(n=5), P F(n=1)$ and both EF and PF $(n=4)$.

For the purpose of evaluating the association between $\mathrm{Tf}$ and prognosis, neoplastic diseases were excluded, and diseases were restricted to the chronic inflammatory gastrointestinal diseases. Twenty dogs histopathologically diagnosed with chronic inflammatory gastrointestinal diseases were recruited. Nine dogs were female (2 intact), and 11 were male (10 intact). The median age was 105.5 months (range: 58-174 months), and the median BCS was 2/5 (range: 1-3). Fifteen dogs were diagnosed with chronic enteritis, 3 were diagnosed with chronic gastritis accompanying pyloric stenosis, and 1 each was diagnosed with chronic colitis and functional ileus. Six of the 20 dogs had apparent ascites due to hypoalbuminemia as a result of protein-losing enteropathy (PLE). The nutritional treatments included OF only $(n=9)$, EF $(n=3), P F(n=6)$ and both EF and PF $(n=2)$.

Measurement of plasma Tf and albumin concentrations: Fasting plasma was separated from heparinized blood and immediately stored at $-20^{\circ} \mathrm{C}$. Plasma Tf concentrations were determined using a commercial kit (Canine Transferrin ELISA kit, GenWay Biotech, San Diego, CA, U.S.A.) according to the manufacturer's protocol; all samples were measured in duplicate. Plasma albumin concentrations were measured using a biochemical analyzer (DRI-CHEM 7000V: Fujifilm Corporation, Tokyo, Japan). Plasma Tf and albumin concentrations were measured at the onset of nutritional treatment (pretreatment) and after treatment (posttreatment). The interval between both time points ranged from 8-30 days. The reference value for the plasma Tf concentration was $180 \mathrm{mg} /$ $\mathrm{d} l$ according to the lower limit of the reference range (i.e., mean $-2 \mathrm{SD}$ ) for healthy dogs [21]. The reference value for the plasma albumin concentration was $2.6 \mathrm{~g} / \mathrm{d} l$ according to the lower limit of our reference range. The survival rate at day 60 after the initial treatment was assessed in each group.

Statistical analysis: Statistical analyses were performed using JMP version 9 (SAS Institute, Cary, NC, U.S.A.). The Wilcoxon Signed-Rank Test was used to compare the preand posttreatment plasma Tf and albumin concentrations. The Fisher's exact test was used to compare the proportion dogs categorized by plasma Tf and albumin concentrations and body weight change. The survival rates at 60 days after the initiation of nutritional treatment were analyzed using the log-rank test. The level of statistical significance was set at $P<0.05$.

\section{RESULTS}

Changes in plasma Tf and albumin concentrations before and after nutritional treatment: Plasma Tf and albumin concentrations were compared before and after nutritional treatment. The median plasma Tf concentrations before and after treatment were $150 \mathrm{mg} / \mathrm{d} l$ (range: $71-320 \mathrm{mg} / \mathrm{d} l$ ) and $190 \mathrm{mg} / \mathrm{d} l$ (range: $39-390 \mathrm{mg} / \mathrm{d} l$ ), respectively. The median plasma albumin concentrations before and after treatment were $2.8 \mathrm{~g} / \mathrm{d} l$ (range: $2.1-3.9 \mathrm{~g} / \mathrm{d} l$ ) and $3 \mathrm{~g} / \mathrm{d} l$ (range: $1.6-3.9$ $\mathrm{g} / \mathrm{d} l$ ). Plasma Tf concentrations were significantly higher after treatment than before treatment $(P<0.05)$ (Fig. 1A). In contrast, plasma albumin concentrations did not differ between before and after treatment $(P=0.5766)$ (Fig. 1B).

The changes in plasma $\mathrm{Tf}$ and albumin concentrations and body weight in each case were subsequently analyzed. Among 15 dogs showing increased plasma Tf concentrations, 10 dogs showed increases in body weight. By contrast, only 1 of the 6 dogs that did not show a change or decrease in plasma $\mathrm{Tf}$ concentration showed an increase in body weight. The proportion of dogs that exhibited increases in plasma $\mathrm{Tf}$ concentrations was significantly related to weight gain $(P<0.05)$ (Table 1). Meanwhile, the numbers of dogs that showed increased plasma albumin concentrations were not significantly related to weight gain $(P=0.4663)$.

Next, the number of dogs with plasma Tf concentrations above the reference range (i.e., $\geq 180 \mathrm{mg} / \mathrm{d} l$ ) was examined [21]. Nine of 11 dogs with increased body weight and 5 of 10 dogs without increase of body weight had $\geq 180 \mathrm{mg} / \mathrm{d} l$ plasma Tf concentrations after treatment, respectively. The number of dogs with plasma Tf concentrations $\geq 180 \mathrm{mg} / \mathrm{d} l$ was not significantly related to body weight gain $(P=0.1223)$ (data not shown).

Survival rates 60 days after nutritional treatment initiation: The dogs were divided into 2 groups according to the Tf and albumin concentrations: plasma Tf concentrations before or after treatment $\geq 180$ and $<180 \mathrm{mg} / \mathrm{d} l$ and plasma albumin concentrations before or after treatment $\geq 2.6$ and $<2.6 \mathrm{~g} / \mathrm{d} l$. The survival rates 60 days after the initiation of treatment for each group are summarized in Table 2. There was a significant difference in the survival rate 60 days after treatment between dogs with posttreatment plasma Tf concentrations $\geq 180 \mathrm{mg} / \mathrm{d} l$ and those with posttreatment plasma Tf concentrations $<180 \mathrm{mg} / \mathrm{d} l(P<0.05)$. The survival rates 60 days after treatment were also significantly different 
A

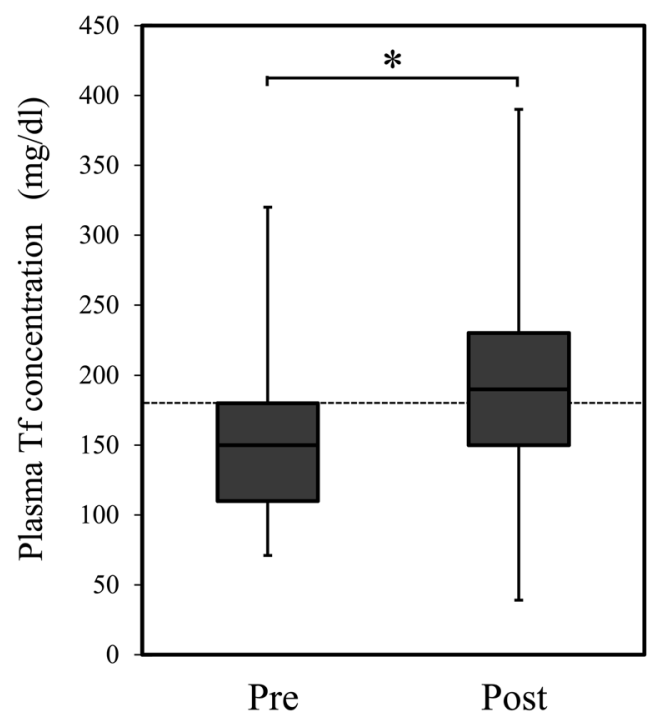

B

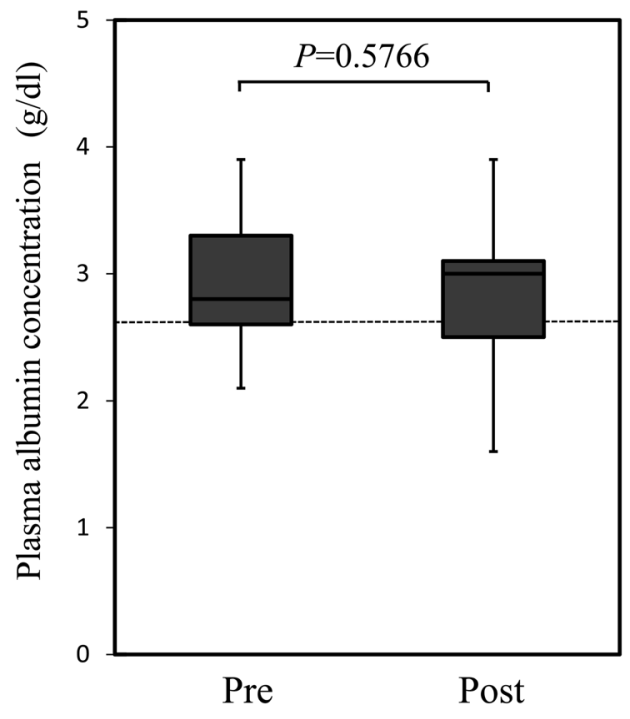

Fig. 1. Plasma transferrin (Tf) (A) and albumin (B) concentrations before and after nutritional treatment. Data are presented as the median with the 25th-75th percentile range in each box plot. Whiskers indicate the highest and lowest data points. Dotted lines show the lower limit of the reference ranges of plasma (A) Tf (i.e., 180 $\mathrm{mg} / \mathrm{d} l$ ) and (B) albumin (i.e., $2.6 \mathrm{~g} / \mathrm{d} l$ ) concentrations. Pre, pretreatment; Post, posttreatment; Tf, transferrin. A significant difference was observed between the pre- and posttreatment Tf concentrations $(P<0.05)$, but not for the albumin concentrations $(P=0.5766)$.

Table 1. Plasma transferrin, albumin concentration and body weight change in dogs with various primary diseases, but without pleural effusion and ascites

\begin{tabular}{llccc}
\hline & & \multicolumn{2}{c}{ Body weight } & \\
\cline { 3 - 4 } & & $\begin{array}{c}\text { Increased } \\
(\mathrm{n}=11)\end{array}$ & $\begin{array}{c}\left.\text { Not changed or decreased }{ }^{\mathrm{b}}\right) \\
(\mathrm{n}=10)\end{array}$ & $P$ values \\
\hline \multirow{2}{*}{ Transferrin } & Increased $(\mathrm{n}=15)$ & 10 & 5 & \multirow{2}{*}{$0.0382^{*}$} \\
& Not changed or decreased $(\mathrm{n}=6)$ & 1 & 5 & \multirow{2}{*}{0.4663} \\
\hline \multirow{2}{*}{ Albumin } & Increased $(\mathrm{n}=8)$ & 5 & 3 & 7 \\
& Not changed or decreased $(\mathrm{n}=13)$ & 6 & & \\
\hline
\end{tabular}

* Statistically significant by Fisher's exact test. a) Number of dogs showing increased body weight after the nutritional therapy. b) Number of dogs in which body weight did not change or decreased after the nutritional therapy.

Table 2. Plasma transferrin, albumin concentration and survival rate on day 60 after the nutritional treatment in dogs histopathologically diagnosed with chronic inflammatory gastrointestinal diseases

\begin{tabular}{lllcc}
\hline & \multicolumn{2}{c}{ Evaluation criteria } & Survival rate $(\%)$ & $P$ value \\
\hline Before treatment & Transferrin $(\mathrm{mg} / \mathrm{d} l)$ & $\begin{array}{l}\geq 180(\mathrm{n}=5) \\
<180(\mathrm{n}=15)\end{array}$ & $\begin{array}{l}60 \\
40\end{array}$ & 0.4655 \\
\cline { 2 - 5 } & Albumin $(\mathrm{g} / \mathrm{d} l)$ & $\begin{array}{l}\geq 2.6(\mathrm{n}=9) \\
<2.6(\mathrm{n}=11)\end{array}$ & $\begin{array}{l}78 \\
18\end{array}$ & $0.0234^{*}$ \\
\hline After treatment & Transferrin $(\mathrm{mg} / \mathrm{d} l)$ & $\begin{array}{l}\geq 180(\mathrm{n}=9) \\
<180(\mathrm{n}=11)\end{array}$ & 78 & \multirow{2}{*}{$0.0147^{*}$} \\
\cline { 2 - 5 } & Albumin $(\mathrm{g} / \mathrm{d} l)$ & $\begin{array}{l}\geq 2.6(\mathrm{n}=7) \\
<2.6(\mathrm{n}=13)\end{array}$ & 71 & 0.1176 \\
\hline
\end{tabular}

* Statistically significant by the log-rank test. 
between dogs with pretreatment plasma albumin concentrations $\geq 2.6 \mathrm{~g} / \mathrm{d} l$ and those with pretreatment plasma albumin concentrations $<2.6 \mathrm{~g} / \mathrm{d} l(P<0.05)$.

\section{DISCUSSION}

We previously reported that plasma Tf concentrations decrease in both anorexic dogs with various diseases and experimentally induced undernourished dogs [21]. The present results show that plasma Tf concentrations changed depending on nutritional state after nutritional treatment. Furthermore, the results suggest that $\mathrm{Tf}$ concentrations after nutritional treatment would be indicative of the prognosis of malnourished dogs with gastrointestinal diseases.

The plasma Tf concentrations increased significantly in many of the malnourished dogs that gained weight after nutritional treatment. Although the rate of change varied among cases, the variation in the plasma Tf concentrations during nutritional treatment could be a useful marker in dogs as well as humans $[12,20,34]$. By contrast, the plasma albumin concentrations did not change significantly before and after treatment. This is considered to be due to the relatively large body pool of albumin in dogs. Therefore, nutritional condition is not reflected by an increased plasma albumin concentration.

The survival rate at day 60 after nutritional treatment was significantly higher in dogs with a plasma Tf concentration $\geq 180 \mathrm{mg} / \mathrm{d} l$. Therefore, the plasma Tf concentration level after nutritional treatment is a candidate prognostic factor for malnourished dogs. In human medicine, patients with higher serum $\mathrm{Tf}$ concentrations have longer survival times than those with lower Tf concentrations $[13,24]$. The present results are concordant with these human studies. Another study showed that an increase in plasma Tf concentration within 4-7 days after the initiation of treatment is associated with better prognosis [23]. As the interval between the 2 measurement points (i.e., before and after treatment) varied among cases (range: 12-29 days) in this study, it is necessary to evaluate the appropriate monitoring time for plasma $\mathrm{Tf}$ concentrations during nutritional treatment. The reference value used in the present study, $180 \mathrm{mg} / \mathrm{d} l$, was defined on the basis of the data of healthy dogs in our previous study [21]. According to the present data, this reference value may be appropriate when using the plasma Tf concentration as a clinical marker of nutritional condition.

Lower plasma albumin concentrations before treatment also influenced the survival rates. Considering that 6 dogs with low plasma albumin concentrations at the onset of treatment were diagnosed with PLE and that hypoalbuminemia is reported to be a prognostic factor of canine chronic enteropathy [1], the significance of the association between survival rate and albumin concentration before treatment is indicative of the severity of PLE itself. As rapid turnover proteins, such as Tf, exhibit preserved blood levels even in human patients with PLE [31], Tf could be especially useful for assessment of the nutritional conditions in dogs with PLE.

This study has several limitations that should be addressed. First, various diseases including malignant tumors were included to evaluate the association between plasma Tf concentrations before and after nutritional treatment. The type of disease and its severity could affect the plasma Tf concentrations. Tf is reported to decrease with infection or inflammation; moreover, the plasma $\mathrm{Tf}$ and C-reactive protein (CRP) concentrations are reported to be negatively correlated $[7,8,15]$. However, CRP was not measured in many dogs in the present study. Second, several nutritional therapies including force feeding, enteral and parenteral feeding and surgery were administered in this study. For example, parenteral intravenous feeding may affect Tf concentrations by altering protein synthesis in the liver. Therefore, additional studies using greater numbers of dogs with a single disease and the same nutritional treatment are required.

In conclusion, to the best of our knowledge, this is the first study demonstrating the clinical usefulness of the plasma Tf concentration as a nutrition assessment marker in dogs. Monitoring the plasma Tf concentration together with the conventional static markers albumin, body weight and BCS could be useful for evaluating nutritional status and prognosis during nutritional treatment in dogs.

\section{REFERENCES}

1. Allenspach, K., Wieland, B., Gröne, A. and Gaschen, F. 2007. Chronic enteropathies in dogs: evaluation of risk factors for negative outcome. J. Vet. Intern. Med. 21: 700-708. [Medline] [CrossRef]

2. Armstrong, P. J. and Lippert, A. C. 1988. Selected aspects of enteral and parenteral nutritional support. Semin. Vet. Med. Surg. (Small Anim.) 3: 216-226. [Medline]

3. Bistrian, B. R., Blackburn, G. L., Scrimshaw, N. S. and Flatt, J. P. 1975. Cellular immunity in semistarved states in hospitalized adults. Am. J. Clin. Nutr. 28: 1148-1155. [Medline]

4. Chan, D. L. 2004. Nutritional requirements of the critically ill patient. Clin. Tech. Small Anim. Pract. 19: 1-5. [Medline] [CrossRef]

5. de Jong, F. A., Howlett, G. J. and Schreiber, G. 1988. Messenger RNA levels of plasma proteins following fasting. Br. J. Nutr. 59: 81-86. [Medline] [CrossRef]

6. Dixon, F. J., Maurer, P. H. and Deichmiller, M. P. 1953. Halflives of homologous serum albumins in several species. Proc. Soc. Exp. Biol. Med. 83: 287-288. [Medline] [CrossRef]

7. Fleck, A. 1989. Clinical and nutritional aspects of changes in acute-phase proteins during inflammation. Proc. Nutr. Soc. 48 : 347-354. [Medline] [CrossRef]

8. Fuhrman, M. P., Charney, P. and Mueller, C. M. 2004. Hepatic proteins and nutrition assessment. J. Am. Diet. Assoc. 104: 1258-1264. [Medline] [CrossRef]

9. Haider, M. and Haider, S. Q. 1984. Assessment of protein-calorie malnutrition. Clin. Chem. 30: 1286-1299. [Medline]

10. Hassanein, el- S. A., Assem, H. M., Rezk, M. M. and elMaghraby, R. M. 1998. Study of plasma albumin, transferrin, and fibronectin in children with mild to moderate protein-energy malnutrition. J. Trop. Pediatr. 44: 362-365. [Medline] [CrossRef]

11. Heyland, D. K. 2000. Enteral and parenteral nutrition in the seriously ill, hospitalized patient: a critical review of the evidence. J. Nutr. Health Aging 4: 31-41. [Medline]

12. Ingenbleek, Y., Van Den Schrieck, H. G., De Nayer, P. and De Visscher, M. 1975. Albumin, transferrin and the thyroxine- 
binding prealbumin/retinol-binding protein (TBPA-RBP) complex in assessment of malnutrition. Clin. Chim. Acta 63: 61-67. [Medline] [CrossRef]

13. Inoue, Y., Nezu, R., Matsuda, H., Takagi, Y. and Okada, A. 1995. Rapid turnover proteins as a prognostic indicator in cancer patients. Surg. Today 25: 498-506. [Medline] [CrossRef]

14. Kalantar-Zadeh, K., Kleiner, M., Dunne, E., Ahern, K., Nelson, M., Koslowe, R. and Luft, F. C. 1998. Total iron-binding capacity-estimated transferrin correlates with the nutritional subjective global assessment in hemodialysis patients. Am. J. Kidney Dis. 31: 263-272. [Medline] [CrossRef]

15. Krzystek-Korpacka, M., Matusiewicz, M., Diakowska, D., Grabowski, K., Blachut, K., Kustrzeba-Wojcicka, I., Terlecki, G. and Gamian, A. 2008. Acute-phase response proteins are related to cachexia and accelerated angiogenesis in gastroesophageal cancers. Clin. Chem. Lab. Med. 46: 359-364. [Medline] [CrossRef]

16. Kuvshinoff, B. W., Brodish, R. J., McFadden, D. W. and Fischer, J. E. 1993. Serum transferrin as a prognostic indicator of spontaneous closure and mortality in gastrointestinal cutaneous fistulas. Ann. Surg. 217: 615-622. [Medline] [CrossRef]

17. Michel, K. E. 1993. Prognostic value of clinical nutritional assessment in canine patients. J. Vet. Emerg. Crit. Care 3: 96-104. [CrossRef]

18. Michel, K. E., Sorenmo, K. and Shofer, F. S. 2004. Evaluation of body condition and weight loss in dogs presented to a veterinary oncology service. J. Vet. Intern. Med. 18: 692-695. [Medline] [CrossRef]

19. Mullen, J. L., Buzby, G. P., Matthews, D. C., Smale, B. F. and Rosato, E. F. 1980. Reduction of operative morbidity and mortality by combined preoperative and postoperative nutritional support. Ann. Surg. 192: 604-613. [Medline]

20. Nakajima, A., Shibazaki, M., Shimetani, N.,Yamaguchi, M. and Mori, M. 2005. Clinical Significance of Measurement of Transfferin, Transthyretin, and Retinol-Binding Protein as Nutrition Assessment Proteins. Dokko. J. Med. Sci. 21-28 (in Japanease).

21. Nakajima, M., Ohno, K., Takeuchi, Y., Takeuchi, A., Nakashima, K., Fujino, Y. and Tsujimoto, H. 2012. Usefulness of plasma transferrin levels as dynamic assessment of protein nutrition in dog. J. Pet. Anim. Nutr. 15: 65-71 (in Japanease).

22. Oka, R., Nakagawa, Y., Shoji, T., Matsuda, Y., Hamamoto, Y. and Takeshita, M. 2006. Usefulness of a nutrition assessment system for parenteral/enteral nutrition therapy. Yakugaku Zasshi 126: 1351-1356. [Medline] [CrossRef]
23. Reddy, S., Adcock, K. J., Adeshina, H., Cooke, A. R., Akene, J. and McFAarlane, H. 1970. Immunity, transferrin, and survival in kwashiorkor. Br. Med. J. 4: 268-270. [Medline] [CrossRef]

24. Reeds, P. J. and Laditan, A. A. 1976. Serum albumin and transferrin protein-energy malnutrition. Their use in the assessment of marginal undernutrition and the prognosis of severe undernutrition. Br. J. Nutr. 36: 255-263. [Medline] [CrossRef]

25. Remillard, R. L., Darden, D. E., Michel, K. E., Marks, S. L., Buffington, C. A. and Bunnell, P. R. 2001. An investigation of the relationship between caloric intake and outcome in hospitalized dogs. Vet. Ther. 2: 301-310. [Medline]

26. Roubenoff, R. and Kehayias, J. J. 1991. The meaning and measurement of lean body mass. Nutr. Rev. 49: 163-175. [Medline] [CrossRef]

27. Seltzer, M. H., Bastidas, J. A., Cooper, D. M., Engler, P., Slocum, B. and Fletcher, H. S. 1979. Instant nutritional assessment. JPEN J. Parenter. Enteral. Nutr. 3: 157-159. [Medline] [CrossRef]

28. Shetty, P. S., Watrasiewicz, K. E., Jung, R. T. and James, W. P. 1979. Rapid-turnover transport proteins: an index of subclinical protein-energy malnutrition. Lancet 2: 230-232. [Medline] [CrossRef]

29. Smale, B. F., Mullen, J. L., Buzby, G. P. and Rosato, E. F. 1981. The efficacy of nutritional assessment and support in cancer surgery. Cancer 47: 2375-2381. [Medline] [CrossRef]

30. Steffee, W. P. 1980. Malnutrition in hospitalized patients. JAMA 244: 2630-2635. [Medline] [CrossRef]

31. Takeda, H., Ishihama, K., Fukui, T., Fujishima, S., Orii, T., Nakazawa, Y., Shu, H. J. and Kawata, S. 2003. Significance of rapid turnover proteins in protein-losing gastroenteropathy. Hepatogastroenterology 50: 1963-1965. [Medline]

32. Thibault, R. and Pichard, C. 2010. Nutrition and clinical outcome in intensive care patients. Curr. Opin. Clin. Nutr. Metab. Care 13: 177-183. [Medline] [CrossRef]

33. Winkler, M. F., Gerrior, S. A., Pomp, A. and Albina, J. E. 1989. Use of retinol-binding protein and prealbumin as indicators of the response to nutrition therapy. J. Am. Diet. Assoc. 89: 684-687. [Medline]

34. Winkler, M. F., Pomp, A., Caldwell, M. D. and Albina, J. E. 1989. Transitional feeding: the relationship between nutritional intake and plasma protein concentrations. J. Am. Diet. Assoc. 89: 969-970. [Medline]

35. Young, M. E. 1988. Malnutrition and wound healing. Heart Lung 17: 60-67. [Medline] 